\title{
Respon akut tekanan darah akibat konsumsi kopi pada wanita sehat
}

\author{
Yusni $^{{ }^{*}}$, Hanifah Yusuf ${ }^{2}$
}

\section{ABSTRACT}

Background: Coffee contains caffeine. Caffeine is the main component that influences the response of the cardiovascular system and blood pressure (BP). Acute response of coffee to increased BP is related to caffeine.

Objectives: This study aims to analyze the acute response of coffee consumption on BP in healthy females therefore coffee is an alternative therapy for hypotension.

Methods: The research design was a clinical trial. Treatment: black coffee, Gayo's Arabica, $10 \mathrm{mg}$, coffee brewed with $150 \mathrm{ml}$ of boiling water, without sugar. BP was examined using a mercury sphygmomanometer and stethoscope. BP each subject was examined twice and averaged. BP was checked 3 times: before, 30, and 60 minutes after coffee consumption. All subjects were non-coffee drinkers. A total of 20 healthy female, 18-20 years old were divided into two groups: the non-intervention $(n=9)$ and intervention $(n=11)$. Data was analyzed by independent and paired sample t-test.

Results: Coffee increased systolic 10-20 $\mathrm{mmHg}$ (14.09\%) and diastolic $3.64 \mathrm{mmHg}$. Coffee lowers $36.36 \%$ of subjects with hypotension. There was no difference between systolic pre-test $(101.11 \pm 12.69 \mathrm{vs} 100.00 \pm 10.00 \mathrm{mmHg} ; \mathrm{p}=0.83)$ and 30 minutes post-intervention $(102.22 \pm 13.01$ vs $101.82 \pm 9.82 \mathrm{mmHg} ; p=0.94)$. There were a significant differences in systolic after 60 minutes post-intervention $(103.33 \pm 11.18$ vs $114.09 \pm 5.84 \mathrm{mmHg} ; p=0.01 *)$ between non-intervention and intervention. There was no difference between diastolic pretest $(70.00 \pm 5.59$ vs. $68.18 \pm 6.03 \mathrm{mmHg} ; p=0.49), 30$ minutes $(70.59 \pm 5.27$ vs. $70.00 \pm 6.33 \mathrm{mmHg} ; p=0.83)$, and 60 minutes post-intervention $(70.00 \pm 5.59 \mathrm{vs} .71 .82 \pm 4.04 \mathrm{mmHg} ; p=0.41)$ between nonintervention and intervention. Data showed that systolic was significantly different $\left(p=0.00^{*}\right)$ after 60 minutes of coffee consumption in the intervention group.

Conclusion: The acute response of coffee consumption to systolic increases was after 60 minutes and not 30 minutes of coffee consumption. Coffee doesn't affect diastolic in healthy women, but it needs further research.

Keywords: coffee; blood pressure; healthy female; caffeine

\begin{abstract}
ABSTRAK
Latar Belakang: Kopi mengandung kafein. Kafein adalah komponen utama yang berpengaruh terhadap respon sistem kardiovaskluler dan tekanan darah (TD). Respon akut kopi terhadap peningkatan TD berkaitan dengan kafein.

Tujuan: Penelitian ini bertujuan menganalisis respon akut konsumsi kopi terhadap TD pada wanita sehat sebagai dasar pemanfaatan kopi sebagai alternatif terapi bagi penderita hipotensi.

Metode: Jenis penelitian adalah uji klinis. Perlakuan: kopi hitam, jenis Arabika Gayo, dosis $10 \mathrm{mg}$, kopi diseduh dengan 150 ml air panas mendidih, tanpa gula. Pemeriksaan TD menggunakan Spygmomanometer air raksa dan stetoskop. TD setiap subjek diperiksa sebanyak dua kali dan kemudian diambil nilai rata-ratanya. TD diperiksa 3 kali: sebelum, menit ke-30 dan menit ke-60 setelah konsumsi kopi. Semua subjek adalah bukan peminum kopi teratur. Total sebanyak 20 orang wanita sehat, usia 18-20 tahun, dibagi dua kelompok: kelompok non-intervensi $(n=9)$ dan intervensi $(n=11)$. Analisis data menggunakan independent dan paired sample t-test.

Hasil: Kopi meningkatkan sistolik 10-20 mmHg (14,09\%) dan diastolik 3,64 mmHg. Kopi menurunkan jumlah penderita hipotensi sekitar 36,36\%. Tidak ada perbedaan antara sistolik pretest $(101,11 \pm 12,69$ vs 100,00 $\pm 10,00 \mathrm{mmHg} ; \mathrm{p}=0,83)$ dan menit ke-30 (102,22 $\pm 13,01$ vs 101,82 $\pm 9,82 \mathrm{mmHg} ; p=0,94)$. Terdapat perbedaan pada sistolik menit ke-60 pasca intervensi $(103,33 \pm 11,18$ vs 114,09 $\pm 5,84 \mathrm{mmHg} ; p=0,01 *)$ antara kelompok non-intervensi dan intervensi. Tidak ada perbedaan antara

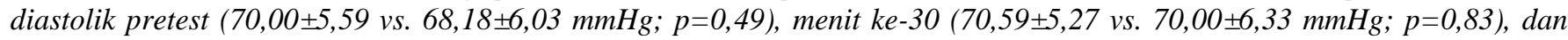
menit ke-60 pasca intervensi $(70,00 \pm 5,59$ vs 71,82 $\pm 4,04 \mathrm{mmHg} ; p=0,41)$ antara kelompok non-intervensi dan intervensi. Data menunjukkan bahwa sistolik berbeda bermakna $\left(p=0,00^{*}\right)$ setelah 60 menit konsumsi kopi pada kelompok intervensi.

Simpulan: Respon akut konsumsi kopi terhadap peningkatan sistolik terjadi setelah 60 menit dan waktu 30 menit belum menimbulkan respon peningkatan TD. Kopi tidak berpengaruh terhadap diastolik pada wanita sehat namun perlu penelitian lanjutan.
\end{abstract}

Kata Kunci: kopi; tekanan darah; wanita sehat; kafein

\footnotetext{
${ }^{1}$ Bagian Fisiologi, Fakultas Kedokteran, Universitas Syiah Kuala. Jl. Teuku Tanoh Abee, Kopelma Darussalam, Syiah Kuala, Banda Aceh 24415, Indonesia.

${ }^{2}$ Bagian Farmakologi, Fakultas Kedokteran, Universitas Syiah Kuala. Jl. Teuku Tanoh Abee, Kopelma Darussalam, Syiah Kuala, Banda Aceh 24415, Indonesia.

*Korespondensi : E-mail: yusni@unsyiah.ac.id
} 


\section{PENDAHULUAN}

Pengaruh konsumsi kopi terhadap tekanan darah masih diperdebatkan. Kopi telah lama dikaitkan dengan tekanan darah dan konsumsi kopi secara teratur dapat meningkatkan tekanan darah., ${ }^{1,2}$ Ada ahli yang berpendapat bahwa konsumsi kopi dosis sedang (3-4 cangkir perhari) aman dan bermanfaat baik bagi orang dengan normotensi, hipertensi, gagal jantung, aritmia jantung dan penderita diabetes. ${ }^{3}$ Penelitian lainnya menyebutkan bahwa kebiasaan konsumsi kopi berhubungan dengan tidak terkontrolnya tekanan darah pada penderita hipertensi. ${ }^{4}$ Kopi mengandung sejumlah senyawa kimia yang mempunyai efek kardiometabolik. ${ }^{5}$ Kafein adalah methylxanthine utama yang ditemukan pada kopi dan bertanggung jawab dalam meningkatkan tekanan darah. ${ }^{6}$ Kafein pada kopi diduga berperan dalam memblok reseptor adenosine dan menghambat fosfodiesterase sehingga meningkatkan tekanan darah. ${ }^{1,7}$ Adenosin adalah suatu vasodilator yang berperan dalam regulator tekanan darah., ${ }^{6,7}$ Efek antagonis kafein terhadap reseptor adenosine inilah yang berperan dalam mekanisme pengaturan tekanan darah pasca konsumsi kopi. ${ }^{8}$ Kafein adalah komponen penting dari kopi, 1 cangkir kopi hitam setara dengan $150 \mathrm{ml}$ mengandung sekitar 60-120 mg kafein. ${ }^{1}$ Kafein merupakan suatu zat yang bersifat stimulan yang berefek terhadap terjadinya palpitasi dan kardiak aritmia pada penderita hipertensi. ${ }^{1}$ Efek kafein diduga memberikan efek positif bagi penderita hipotensi. Kafein merangsang sistem saraf simpatis, korteks adrenal, dan sistem renin angiotensin. ${ }^{7}$ Melalui jalur inilah diduga kopi dapat meningkatkan tekanan darah pada orang normal dan juga penderita hipertensi, namun penelitian ini hanya menganalisis pengaruh kopi pada orang normal.

Efek akut konsumsi kafein menunjukkan bahwa pemberian kafein dosis $3,3 \mathrm{mg} / \mathrm{kg}$ atau rata-rata sekitar 250-260 mg (atau setara dengan 2 cangkir (300-400 $\mathrm{ml})$ ) menyebabkan peningkatan secara bermakna terhadap TD sistolik dan diastolik pada orang dengan normotensi dan hipertensi, namun kami belum menemukan referensi terhadap penderita hipotensi. ${ }^{9}$ Penelitian tentang respon akut dari konsumsi kopi terhadap tekanan darah pada penderita hipertensi menunjukkan bahwa kafein kopi dapat meningkatkan tekanan darah selama $\geq 3$ jam pasca konsumsi kopi. ${ }^{10}$ Konsumsi 200-300 mg kafein atau setara 2-3 cangkir kopi dapat meningkatkan TD sistolik sebesar 8,1 mmHg dan diastolik 5,7 mmHg. ${ }^{10}$ Kafein meningkatkan resistensi vaskuler sehingga konsumsi kopi jangka panjang diduga berpotensi meningkatkan risiko terjadinya hipertensi. ${ }^{9}$ Kebiasaan konsumsi kopi lebih dari 3 cangkir perhari dapat meningkatkan risiko terjadinya hipertensi sekunder. ${ }^{11}$ Kami menduga bahwa konsumsi kopi bermanfaat untuk meningkatkan tekanan darah sehingga dapat dikonsumsi oleh penderita hipotensi. Hipotensi adalah suatu kondisi rendahnya tekanan darah (sistolik $<90$ dan diastolik $<60 \mathrm{mmHg}$ ) atau terjadinya penurunan tekanan darah sekitar 20/10 mmHg yang bersifat kronis. ${ }^{12}$

Penelitian sejenis tentang efek akut konsumsi kopi terhadap tekanan darah pada peminum kopi teratur dan bukan peminum kopi menyebutkan bahwa pemberian 2,5 g kafein kopi yang diseduh dengan 150 $\mathrm{ml}$ air panas dapat meningkatkan tekanan darah setelah 30 menit, 60 menit dan 90 menit. ${ }^{13}$ Penelitian tersebut berbeda dengan yang kami lakukan karena penelitian ini memberikan kopi hitam bubuk khusus jenis Arabika Gayo dosis $10 \mathrm{mg}$ yang diseduh dengan $150 \mathrm{ml}$ air panas. Kami menggunakan jenis kopi Arabika Gayo karena berdasarkan hasil obsevasi kami di masyarakat (penelitian pendahuluan dan belum dipublikasikan) menemukan bahwa sebagian besar masyarakat Aceh mengkonsumsi kopi Arabika. Selain itu, efek kopi kemungkinan dipengaruhi oleh jenis dan varians kopi, oleh karena itu kami melakukan penelitian dengan menggunakan kopi yang berasal dari Aceh yaitu daerah Gayo.

Penelitian ini bertujuan untuk menganalisis respon akut dari konsumsi kopi Arabika Gayo terhadap tekanan darah pada wanita sehat yang bukan peminum kopi karena kemungkinan hasil penelitian akan berbeda jika menggunakan peminum kopi teratur. Konsumsi kopi teratur dapat mengakibatkan efek toleransi terhadap kafein kopi, namun mekanisme yang pasti masih belum diketahui. ${ }^{13}$ Hasil penelitian ini bermanfaat untuk menjadikan kopi sebagai alternatif terapi bagi penderita hipotensi dan juga menjelaskan bahaya konsumsi kopi bagi penderita hipertensi. Penelitian ini juga ingin menemukan waktu mulai terjadinya peningkatan tekanan darah setelah konsumsi kopi. Penelitian ini merupakan penelitian pendahuluan dan sebagai acuan untuk penelitian lanjutan.

\section{BAHAN DAN METODE}

Jenis penelitian yang digunakan adalah uji klinis fase 1 karena penelitian ini menggunakan subjek manusia sehat. Penelitian ini memberikan intervensi pada subjek penelitian. Intervensi yang diberikan berupa kopi hitam, bubuk, tanpa gula, dosis $10 \mathrm{mg}$, diseduh dengan $150 \mathrm{ml}$ air panas mendidih, dan jenis kopinya adalah Arabica Gayo. Kopi dibeli langsung dari daerah penghasil kopi di Aceh yaitu di daerah Gayo (Desa Bener Meriah, Kabupaten Aceh Tengah, Aceh). Penentuan dosis kopi didasarkan pada takaran sajian kopi yang biasa dikonsumsi oleh masyarakat. Dosis ini kami gunakan dengan tujuan untuk mengukur respon dari konsumsi kopi dosis fisiologis terhadap 
perubahan akut tekanan darah pada orang sehat. Penelitian ini juga merupakan penelitian pendahuluan yang akan dilanjutkan ke tahapan berikutnya, oleh karena itu dosis takaran harian ini akan menjadi acuan untuk penggunaan dosis kopi untuk penelitian lanjutan yang sejenis.

Subjeknya adalah wanita dengan kriteria insklusinya adalah usia antara 18-20 tahun, sehat jasmani dan rohani berdasarkan hasil anamnesis dan pemeriksaan fisik oleh dokter, cukup tidur (6-8 jam dalam waktu 24 jam), tidak mengkonsumsi kopi secara teratur (tidak minum kopi setiap hari atau konsumsi kopi <1 gelas perhari dan tidak rutin), dan tidak menderita hipertensi. Kriteria eksklusinya adalah subjek penelitian tidak mengikuti sepenuhnya prosedur penelitian, mengalami gangguan kesehatan pada masa penelitian sehingga mengganggu jadwal penelitian, menolak untuk ikut berpartisipasi dalam penelitian setelah mendapatkan informed consent, dan tidak dapat mengkonsumsi kopi. Pemilihan subjek wanita didasarkan pada jumlah subjek laki-laki lebih sedikit dari wanita.

Total jumlah populasinya adalah sebanyak 36 orang. Dari jumlah 36 orang terdapat sebanyak 28 orang wanita dan 8 orang laki-laki. Setelah mendapatkan informed consent (sehari sebelum pemeriksaan) dari 28 wanita sebanyak 22 orang bersedia menjadi subjek penelitian. Kemudian subjek dibagi kedalam 2 kelompok, yaitu: 11 orang kelompok non-intervensi dan 11 orang kelompok intervensi (diberikan kopi Arabika seduh). Pada hari pelaksanaan penelitian sebanyak 2 orang subjek dari kelompok nonintervensi tidak hadir, oleh karena itu total subjek menjadi 20 orang dengan rincian 9 orang sebagai kelompok non-intervensi dan 11 orang sebagai kelompok intervensi. Jumlah sampel ditentukan berdasarkan hitung sampel menggunakan rumus ukuran sampel untuk penelitian eksperimental. Pemilihan subjek sebagai kelompok non-intervensi dan intervensi ditentukan dengan menggunakan simple random sampling sistem undian. Semua subjek dianjurkan untuk tidak mengkonsumsi kopi dan minuman yang mengandung kafein lainnya seperti: teh, soft drink, dan minuman berenergi minimal 24 jam sebelum pemeriksaan.

Pemeriksaan yang dilakukan adalah antropometri (berat badan, tinggi badan, dan Indeks Massa Tubuh (IMT)), dan pemeriksaan TD sistolik dan diastolik. IMT diukur dengan menggunakan rumus hitung IMT, yaitu berat badan $(\mathrm{kg})$ dibagi tinggi badan $\left(\mathrm{m}^{2}\right)$ dikuadratkan. ${ }^{14}$ Pengukuran berat badan menggunakan timbangan manual dengan merek ZT-120 GEA dengan toleransi kesalahan sekitar $0,1 \mathrm{~kg}$. Pengukuran tinggi badan menggunakan skala pengukur tinggi badan dengan tingkat toleransi kesalahan sekitar $0,1 \mathrm{~cm}$. Pengukuran TD dilakukan sebanyak 3 kali, yaitu: sebelum diberikan intervensi, 30 menit setelah (pasca) intervensi, dan 60 menit setelah intervensi. Alat pengukur TD yang digunakan adalah Sphygmomanometer air raksa (model Riester Nova Ecoline) dan Stetoskop Littmann dengan toleransi kesalahan sekitar $\pm 2 \quad \mathrm{mmHg}$. Langkah-langkah pengukuran tekanan darah, sebagai berikut ${ }^{15}$ : (1) Subjek diminta untuk rileks dengan posisi duduk di kursi dengan kaki rata di lantai dan punggung ditopang. Subjek duduk 3-5 menit tanpa berbicara atau bergerak. (2) Subjek tidak minum kopi, tidak olahraga dan tidak merokok 30 menit sebelum pemeriksaan, (3) Pasang manset pada lengan atas kira-kira 2,5-5 $\mathrm{cm}$ di atas siku, jangan terlalu ketat dan pasang yang rapi, (4) Raba arteri brachialis dengan menggunakan tiga jari dan pasang stetoskop, (5) Lakukan pemompaan manset sampai kira-kira $30 \mathrm{mmhg}$ di atas tekanan ketika pulsasi arteri brachialis menghilang dan untuk pembacaan auskultasi, turunkan tekanan manset sekitar 2 $\mathrm{mmHg} / \mathrm{detik}$ sehingga terdengar bunyi Korotkoff, tentukan tekanan sistolik (6) Turunkan tekanan manset secara perlahan sampai teraba kembali denyutan arteri brachialis sehingga terdengar sistolik. (6) Lakukan penurunan tekanan manset sampai suara dari denyutan melemah dan kemudian menghilang dan inilah yang disebut tekanan diastolik. (7) Pengukuran dilakukan sebanyak 2 kali dan nilai yang didapat adalah nilai ratarata.

Pemilihan waktu ini dilakukan untuk melihat kapan mulai timbul pengaruh kopi terhadap peningkatan tekanan darah. Semua pemeriksaan dilakukan oleh dokter yang bukan merupakan tim peneliti dengan tujuan untuk menjamin validitas data. Penelitian ini dilaksanakan Agustus hingga Oktober 2019. Waktu tiga bulan dibutuhkan mulai dari pemilihan subjek penelitian, skrining sampel penelitiannya, persiapan alat dan bahan penelitian. Tempat penelitian adalah di Laboratorium Fisiologi, Fakultas Kedokteran (FK) Unsyiah. Penelitian ini telah mendapatkan persetujuan etik dari Komite Etik Penelitian Kedokteran (KEPK) FK Unsyiah dengan nomor: 261/EA/FK-RSUDZA/2019.

Analisis data penelitian menggunakan program software komputer. Langkah-langkah analisis data adalah analisis normalitas Kolmogorov-Smirnov $(\mathrm{p}<0,05)$ dan homogenitas Levene's test $(p<0,05)$. Berdasarkan analisis ini menunjukkan bahwa data berdistribusi nomal dan homogen, oleh karena itu untuk menguji pengaruh konsumsi kopi terhadap tekanan darah dilakukan analisis $t$-test $(p<0,05)$ yang terdiri dari Independent sample t-test $(p<0,05)$ dan paired sample ttest $(p<0,05)$. Independent sample t-test dilakukan untuk mengetahui perbedaan TD sebelum dan setelah perlakuan antara kelompok non-intervensi dan intervensi. Analisis paired sample t-test $(p<0,05)$ dilakukan untuk mengetahui perbedaan TD antara 
sebelum dan sesudah 30 menit intervensi dan juga perbedaan TD antara sebelum dan sesudah 60 menit intervensi pada masing-masing kelompok. Hasil ini akan memberikan gambaran ada tidaknya pengaruh konsumsi terhadap peningkatan TD.

\section{HASIL}

\section{Data Karakteristik Subjek}

Tabel 1 menggambarkan tentang data karakteristik yang meliputi data demografi seperti umur, berat badan, tinggi badan, dan IMT dari subjek penelitian. Hasil analisis data demografi menunjukkan bahwa tidak adanya perbedaan yang signifikan terhadap umur $(p=0,75)$, berat $(p=0,07)$, tinggi $(p=0,25)$, dan IMT $(p=0,16)$ antara kelompok non intervensi dan kelompok intervensi. Umur minimum dan maksimum dari subjek kelompok kontrol dan perlakuan adalah sama, yaitu 18 dan 20 tahun.

Gambaran Tekanan Darah Sebelum dan Setelah Konsumsi Kopi pada Kelompok Non-Intervensi dan Intervensi

Gambaran perubahan tekanan darah sebelum, menit ke-30, menit ke-60 setelah mengkonsumsi kopi dapat dilihat pada gambar 1 . Konsumsi kopi dapat meningkatkan TD sistolik sekitar 14,09\% setelah 60 menit mengkonsumsi kopi. Peningkatan sistolik ratarata berkisar antara $10-20 \mathrm{mmHg}$ dan peningkatan TD ini masih dalam batas normal. Hasil ini menunjukkan bahwa konsumsi kopi terbukti dapat meningkat sistolik pada wanita normal. Oleh karena itu, kopi dapat dikonsumsi untuk meningkatkan TD pada orang dengan hipotensi, namun tidak dapat dikonsumsi bagi mereka yang memiliki riwayat hipertensi. Gambar 1 juga menunjukkan bahwa TD diastolik pada kelompok intervensi sedikit mengalami peningkatan pada menit ke-30 (meningkat sekitar 1,82 mmHg) dan menit ke-60 (meningkat sekitar 3,64).

Gambar 2 menunjukkan gambaran TD pada kelompok non-intervensi. Selisih TD sistolik sebelum intervensi dengan setelah 30 menit dan 60 menit setelah intervensi adalah sebesar $0,89 \mathrm{mmHg}$ dan $2,22 \mathrm{mmHg}$. Hal ini menunjukkan adanya sedikit peningkatan TD sistolik setelah 30 menit dan 60 menit intervensi pada kelompok non-intervensi. Namun untuk melihat ada tidaknya pengaruh pemberian kopi terhadap TD dilakukan analisis lanjutan menggunakan uji-t seperti yang terlihat pada tabel 2 dan 3 .

Gambar 3 memberikan gambaran tentang jumlah subjek yang memiliki tekanan darah normal (normotensi) dan tekanan darah dibawah normal (hipotensi) pada kelompok intervensi. Kriteria hipotensi adalah sistolik $\leq 90 \mathrm{mmHg}$ dan diastolik $\leq 60 \mathrm{mmHg}$. Sebelum pemberian kopi jumlah subjek dengan hipotensi adalah sebanyak 4 orang atau sekitar $36,36 \%$, namun jumlah subjek yang dengan hipotensi menurun (dari 36,36\% menjadi 0\%) setelah 60 menit konsumsi kopi dan tidak ada penurunan jumlah subjek dengan hipotensi setelah 30 menit konsumsi kopi. Hasil penelitian ini memberikan gambaran bahwa mengkonsumsi kopi dapat menurunkan jumlah penderita hipotensi pada wanita sehat, namun ini merupakan respon akut dan perlu dilanjutkan dengan menguji respon kronis dari konsumsi kopi.

Tabel 1. Data Demografi Subjek

\begin{tabular}{llcc}
\hline \multirow{2}{*}{ Data } & \multicolumn{2}{c}{ Kelompok } & \multicolumn{1}{c}{$\boldsymbol{p}$} \\
\cline { 2 - 4 } & \multicolumn{1}{c}{ Non-Intervensi (n=9) } & $18,82 \pm 0,63$ & 0,75 \\
Umur (tahun) & $18,89 \pm 0,61$ & $53,77 \pm 7,03$ & 0,07 \\
Berat badan $(\mathrm{kg})$ & $47,39 \pm 7,65$ & $157,00 \pm 4,31$ & 0,25 \\
Tinggi badan $(\mathrm{cm})$ & $154,61 \pm 4,63$ & $21,86 \pm 3,19$ & 0,16 \\
IMT $\left(\mathrm{kg} / \mathrm{m}^{2}\right)$ & $19,81 \pm 3,02$ & \\
\hline
\end{tabular}

Keterangan: IMT=Indeks Massa Tubuh; $p<0,05=$ bermakna pada taraf kekeliruan 5\%

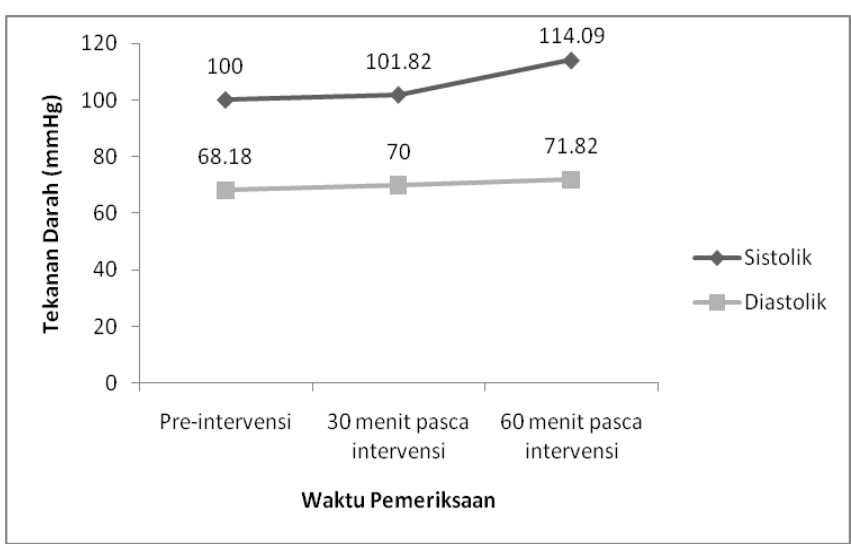

Gambar 1. Respon Peningkatan Tekanan Darah Sebelum dan Setelah Konsumsi Kopi pada Kelompok Intervensi

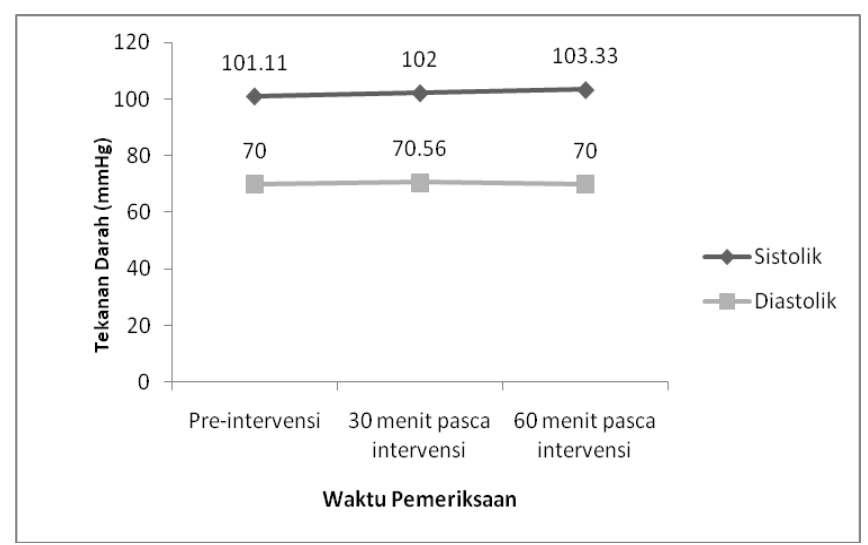

Gambar 2. Respon Peningkatan Tekanan Darah Sebelum dan Setelah Konsumsi Kopi pada Kelompok NonIntervensi 


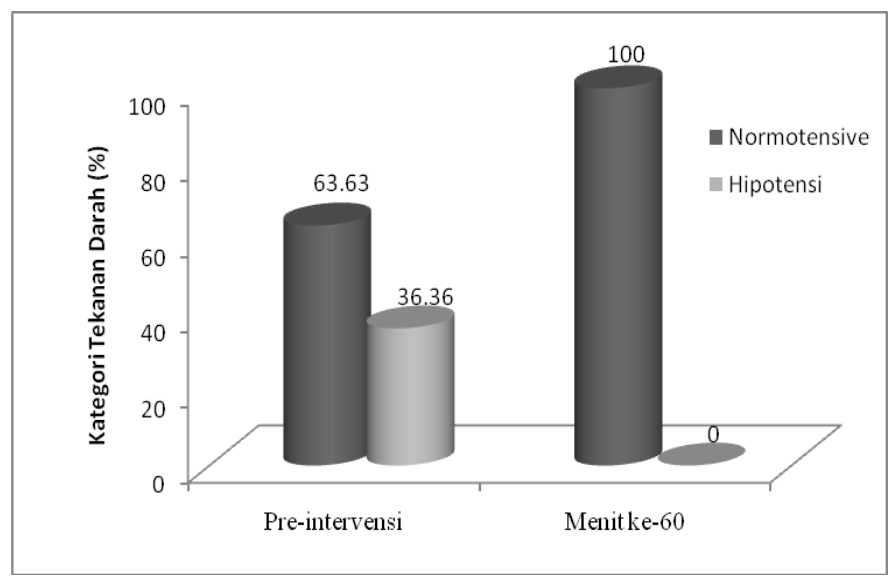

Gambar 3. Persentase Penurunan Jumlah Hipotensi Setelah Pemberian Kopi (Menit Ke-60) Pada Kelompok Intervensi

Hasil analisis tekanan darah pada kelompok nonintervensi dan intervensi

Berdasarkan analisis data TD didapatkan bahwa tidak ada perbedaan pada TD sistolik pretest $(p>0,05)$ dan menit ke-30 ( $p>0,05)$ antara kelompok nonintervensi (kontrol) dan intervensi (konsumsi kopi), seperti yang terlihat pada tabel 2. Terdapat perbedaan signifikan antara TD sistolik pre-intervensi dengan menit ke-60 pasca intervensi antara kelompok nonintervensi dan kelompok intervensi $(p=0,01)$. Hal ini mengindikasikan bahwa kopi dapat memberikan respon terhadap peningkatan TD sistolik setelah 60 menit mengkonsumsi kopi pada wanita sehat. Pengaruh konsumsi kopi terhadap TD diastolik menunjukkan bahwa tidak ada perbedaan TD diastolik pre-intervensi $(p>0,05)$, menit ke-30 ( $p>0,05)$, dan menit ke- 60 pasca intervensi $(p>0,05)$ antara kelompok non-intervensi dengan kelompok intervensi. Hasil ini menunjukkan bahwa konsumsi kopi tidak berpengaruh terhadap TD diastolik pada wanita sehat.

Tabel 3 menunjukkan data hasil analisis paired $t$ test mengenai perbedaan pengaruh konsumsi kopi terhadap tekanan darah pada masing-masing kelompok. Hasilnya adalah sistolik dan diastolik antara preintervensi dan menit ke-30 pasca intervensi tidak berbeda baik pada kelompok non-intervensi maupun kelompok intervensi $(p>0,05)$. Hasil ini menunjukkan bahwa setelah 30 menit komsumsi kopi tidak memberikan efek terhadap TD.

Hasil analisis paired sample t-test untuk menganalisis pengaruh setelah 60 menit konsumsi kopi terhadap tekanan darah pada kelompok non-intervensi dan intervensi dapat dilihat pada tabel 4. Hasilnya menjelaskan bahwa TD sistolik dan diastolik pada kelompok non-intervensi tidak menunjukkan adanya perbedaan sebelum dan setelah intervensi $(p>0,05)$. Hasil analisis menunjukkan bahwa TD sistolik berbeda bermakna setelah 60 menit mengkonsumsi kopi $(p<0,05)$. Hasil analisis ini menunjukkan bahwa kopi dapat meningkatkan TD sistolik setelah 60 menit konsumsi. Namun sebaliknya terdapat perbedaan yang tidak bermakna antara TD diastolik sebelum dan setelah 60 menit minum kopi $(p>0,05)$ pada kelompok nonintervensi dan intervensi.

Tabel 2. Perbedaan Sistolik dan Diastolik pada Kedua Kelompok

\begin{tabular}{|c|c|c|c|c|}
\hline \multirow{2}{*}{\multicolumn{2}{|c|}{ Tekanan darah }} & \multicolumn{2}{|c|}{ Kelompok } & \multirow{2}{*}{ p-value } \\
\hline & & Non-Intervensi $(n=9)$ & Intervensi $(n=11)$ & \\
\hline \multirow{3}{*}{ Sistolik (mmHg) } & Pre-intervensi & $101,11 \pm 12,69$ & $100 \pm 10,00$ & 0,83 \\
\hline & Menit ke-30 & $102,22 \pm 13,01$ & $101,82 \pm 9,82$ & 0,94 \\
\hline & Menit ke-60 & $103,33 \pm 11,18$ & $114,09 \pm 5,84$ & $0,01 *$ \\
\hline \multirow{3}{*}{ Diastolik (mmHg) } & Pre-intervensi & $70,00 \pm 5,59$ & $68,18 \pm 6,03$ & 0,49 \\
\hline & Menit ke-30 & $70,56 \pm 5,27$ & $70,00 \pm 6,33$ & 0,83 \\
\hline & Menit ke-60 & $70,00 \pm 5,59$ & $71,82 \pm 4,05$ & 0,41 \\
\hline
\end{tabular}

*Independent sample t-test $(p<0,05)$ terdapat perbedaan yang signifikan

Tabel 3. Analisis Paired Sample T-Test untuk Mengetahui Perbedaan Sistolik dan Diastolik Pre dan Menit Ke-30 Menit Pasca Intervensi pada Kedua Kelompok

\begin{tabular}{|c|c|c|c|c|c|c|}
\hline \multirow{2}{*}{ Kelompok } & \multicolumn{2}{|c|}{ Sistolik (mmHg) } & \multirow{2}{*}{$p$-value } & \multicolumn{2}{|c|}{ Diastolik (mmHg) } & \multirow{2}{*}{$p$-value } \\
\hline & Pre-Intervensi & Menit ke-30 & & Pre-Intervensi & Menit ke-30 & \\
\hline Non-intervensi & $101,11 \pm 12,69$ & $102,22 \pm 13,02$ & 0,35 & $70,00 \pm 5,59$ & $70,56 \pm 5,27$ & 0,35 \\
\hline Intervensi & $100 \pm 10,00$ & $101,82 \pm 9,82$ & 0,17 & $68,18 \pm 6,03$ & $70,00 \pm 6,33$ & 0,58 \\
\hline
\end{tabular}

*paired sample t-test $(p<0,05)$ terdapat perbedaan yang signifikan

Tabel 4. Perbedaan Sistolik dan Diastolik Pre dan Pasca 60 Menit Intervensi pada Kelompok Kontrol dan Intervensi

\begin{tabular}{|c|c|c|c|c|c|c|}
\hline \multirow{2}{*}{ Kelompok } & \multicolumn{2}{|c|}{ Sistolik (mmHg) } & \multirow{2}{*}{ p-value } & \multicolumn{2}{|c|}{ Diastolik (mmHg) } & \multirow{2}{*}{$p$-value } \\
\hline & Pre-Intervensi & Menit ke-60 & & Pre-Intervensi & Menit ke-60 & \\
\hline Non-intervensi & $101,11 \pm 12,69$ & $103,33 \pm 11,18$ & 0,16 & $70,00 \pm 5,59$ & $70,00 \pm 5,59$ & 1,00 \\
\hline Intervensi & $100 \pm 10,00$ & $114,09 \pm 5,84$ & $0,00 *$ & $68,18 \pm 6,03$ & $71,82 \pm 4,05$ & 0,11 \\
\hline
\end{tabular}

*paired sample $t$-test $(p<0,05)$ terdapat perbedaan yang signifikan 


\section{PEMBAHASAN}

Kopi mengandung lebih dari 1000 senyawa bioaktif diantaranya; kafein, alkohol diterpen (cafestol dan kaweol), quinide, lignan, trigomellie, dan Chlorogenic acid (CGA).,16 Kafein setelah diminum segera akan diabsorpsi oleh sistem digestif dan membutuhkan waktu sekitar 30-45 menit. $^{3}$ Kafein dimetabolisme di hati oleh enzim sitokrom P450 1A2 atau disingkat dengan CYP1A2. ${ }^{3}$ Kafein memiliki efek fisiologis terhadap sistem saraf pusat, sistem kardiovaskular, sistem pernapasan, dan sistem endokrin. ${ }^{17}$ Kafein mempengaruhi sistem kardiovaskuler yaitu meningkatkan tekanan darah. ${ }^{17}$ Pengaruh kafein terhadap peningkatan tekanan darah sudah dilaporkan sejak lebih dari 75 tahun yang lalu. ${ }^{18}$ Respon akut konsumsi kafein berefek terhadap peningkatan tekanan darah dengan cara meningkatkan renin dan katekolamin. ${ }^{18,19}$ Kafein bekerja dengan memblok aktivitas reseptor adenosin dan sebagai antagonis adenosin, kafein juga secara langsung menghambat pelepasan adenosin endogen..$^{20,21}$

Adenosin adalah nukleosida adenin yang berperan mengatur hemodinamik jantung dan endotel pembuluh darah. ${ }^{3}$ Adenosin merupakan mediator pelepasan nitrit oksida. ${ }^{20}$ Nitrit oksida adalah suatu vasodilator kuat yang dihasilkan oleh endotel pembuluh darah. ${ }^{20}$ Melalui jalur ini, kafein berperan dalam meningkatkan vasokontriksi pembuluh darah dan resistensi perifer total. ${ }^{20}$ Respon akut ini mungkin akan berbeda dengan respon konsumsi kopi jangka panjang terhadap tekanan darah karena konsumsi secara teratur akan mengakibatkan efek toleransi kafein terhadap tubuh. ${ }^{17}$ Konsumsi kafein teratur melebihi $400 \mathrm{mg}$ perhari akan membahayakan kesehatan jantung. ${ }^{17}$ Batas konsumsi kopi yang aman untuk kesehatan manusia adalah 2-3 cangkir sehari. ${ }^{16}$ Kandungan kafein kopi Arabika Gayo adalah sekitar 0,194-0,328\%. ${ }^{22,23}$

Kami menemukan bahwa bahwa konsumsi kopi meningkatkan secara signifikan TD sistolik $(p<0,05)$, namun tidak berpengaruh bermakna terhadap TD diastolik $(p>0,05)$. Hasil penelitian ini sejalan dengan penelitian terhadap 1329 orang usia antara 20-60 tahun di Ankara, Turki yang menyebutkan bahwa konsumsi kafein rata-rata sebesar 150,0 $\pm 122,06 \mathrm{mg}$ perhari tidak berpengaruh terhadap TD diastolik, namun berkorelasi positif $(p<0,05)$ dengan TD sistolik. ${ }^{17}$ Penelitian lainnya yang dilakukan terhadap 165 wanita dan laki-laki sehat berusia antara 35-64 tahun menunjukkan bahwa konsumsi kafein dosis $250 \mathrm{mg}$ sehari selama 6 hari dapat meningkatkan tekanan darah. ${ }^{24}$ Berbeda dengan penelitian yang dilakukan terhadap wanita sehat yang diberikan kopi Arabika tanpa gula, dosis $500 \mathrm{ml} / \mathrm{hari}$ dengan frekuensi $5 \mathrm{x} /$ minggu, dan diberikan selama 4 minggu tidak menunjukkan adanya perubahan terhadap tekanan darah. ${ }^{25}$
Asupan kafein sekitar 3,3-6 $\mathrm{mg} / \mathrm{kgBB}$ meningkatkan TD sistolik antara 5-15 $\mathrm{mmHg}$ dan diastolik sekitar 5-10 mmHg. ${ }^{21}$ Penelitian lainnya menyebutkan bahwa konsumsi $250 \mathrm{mg}$ kafein meningkatkan TD sistolik sekitar 12,6 dan TD diastolik sebesar 7,1 mmHg pada orang sehat dengan normotensi yang tidak terbiasa minum kopi maupun pada yang terbiasa konsumsi kopi. ${ }^{26}$ Kafein adalah komponen utama pada kopi yang berperan terhadap peningkatan TD akut pada peminum kopi. ${ }^{16}$ Efek akut dari kafein kopi adalah bersifat sementara dan kafein kopi yang dikonsumsi dapat bertahan di dalam tubuh selama 3 jam. ${ }^{5,16}$ Namun asupan teratur dan jangka panjang menyebabkan terjadinya efek toleransi tubuh terhadap kafein sehingga akan memberikan dampak yang berbeda jika penelitian ini dilakukan dalam jangka panjang. ${ }^{16}$ Selain itu, efek akut konsumsi kopi juga akan berbeda pada orang yang tidak terbiasa minum kopi dan peminum kopi rutin yaitu kopi meningkatkan tekanan darah secara akut pada peminum kopi yang tidak terbiasa minum kopi namun tidak berpengaruh terhadap TD akut pada peminum kopi teratur atau orang dengan kebiasaan konsumsi kopi setiap hari. ${ }^{16}$ Konsumsi kopi tidak melebihi 6 cangkir ( 1 cangkir setara dengan \pm 150 ml) perhari tidak meningkatkan risiko terjadinya hipertensi. ${ }^{16}$ Konsumsi kopi $\geq 3$ cangkir perhari mengakibatkan tekanan darah lebih tinggi selama 24 jam pada lanjut usia. ${ }^{4}$

\section{KETERBATASAN PENELITIAN}

Penelitian hanya dilakukan pada subjek yang berjenis kelamin wanita sehingga tidak dapat membandingkan dengan subjek yang berjenis kelamin laki-laki. Oleh karena itu penelitian ini dapat dilanjutkan pada subjek laki-laki sebagai kelompok pembanding. Intervensi hanya menggunakan satu jenis kopi (Arabika) sehingga dapat dilakukan penelitian dengan melakukan pembanding menggunakan kopi jenis lainnya seperti Robusta. Hal ini dikarenakan efek akut konsumsi kopi terhadap TD dipengaruhi oleh kandungan kafein yang terdapat pada kopi. Kopi Robusta mengandung kadar kafein yang lebih tinggi dibandingkan dengan kopi Arabika dan hal ini kemungkinan akan memberikan efek yang berbeda. Penelitian ini dilakukan pada subjek normotensi dan perlu dilakukan pada subjek dengan hipotensi agar dapat memberikan manfaat konsumsi kopi sebagai nonfarmakologis terapi pada pasien hipotensi kronis.

\section{SIMPULAN}

Respon akut konsumsi kopi terhadap tekanan darah yaitu terjadi peningkatan sistolik sekitar 10-20 $\mathrm{mmHg}$ atau sekitar $14,09 \%$ setelah 60 menit mengkonsumsi kopi namun tidak berpengaruh terhadap 
diastolik pada wanita sehat. Konsumsi kopi juga menurunkan jumlah penderita hipotensi sekitar 36,36\%, oleh karena itu kopi berpotensi untuk dikembangkan sebagai alternatif terapi untuk penderita hipotensi dan tidak dianjurkan bagi penderita hipertensi. Perlu penelitian lanjutan untuk mengukur efek kronis konsumsi kopi terhadap tekanan darah pada orang normal, hipotensi dan hipertensi.

\section{UCAPAN TERIMA KASIH}

Penelitian ini didanai melalui pendanaan hibah penelitian sumber dana Universitas Syiah Kuala (Unsyiah) tahun 2019. Terima kasih kepada Lembaga Penelitian dan Pengabdian Masyarakat (LPPM) Unsyiah atas supportnya dalam pelaksanaan penelitian ini. Terima kasih yang sebesar-besarnya kepada semua subjek yang dengan sukarela bersedia mengikuti penelitian ini.

\section{DAFTAR PUSTAKA}

1. Nurminen M, Niittynen L, Korpela R, Vapaatalo H. Coffee, caffeine and blood pressure: a critical review. Eur J Clin Nutr. 1999;53(March 2014):831-9.

2. Noordzij M, Uiterwaal CSPM, Arends LR, Kok FJ, Grobbee DE, Geleijnse JM. Blood pressure response to chronic intake of coffee and caffeine: a meta-analysis of randomized controlled trials. $J$ Hypertens. 2005;23(5):921-8.

3. Chrysant SG. The impact of coffee consumption on blood pressure, cardiovascular disease and diabetes mellitus. Expert Rev Cardiovasc Ther. 2017;15(3):151-6.

4. Graciani A, Banegas JR, Rodríguez- F. Habitual coffee consumption and 24-h blood pressure control in older adults with hypertension. Clin Nutr. 2016;35(6):1457-63.

5. Mesas AE, Leon-Muñoz LM, Rodriguez-Artalejo F, Lopez-Garcia E. The effect of coffee on blood pressure and cardiovascular disease in hypertensive individuals: a systematic review and meta-analysis. Am J Clin Nutr 2011. 2011;94:1113-26.

6. Souza AA, Silva RSB, Silva TF, Tavares RL, Silva AS. Influence of different doses of coffee on postexercise blood pressure response. Am J Cardiovasc Dis. 2016;6(4):146-52.

7. Mort JR, Kruse HR. Timing of Blood Pressure Measurement Related to Caffeine Consumption. Ann Pharmacother. 2008;42:105-10.

8. Ruiz R, Ramos SDP, Pinge MM, Moraes SF De, Polito M. Caffeine and physical training: effects on cardiac morphology and cardiovascular response. Rev Assoc Med Bras. 2014;60(1):23-28.
9. Hartley TR, Sung BH, Pincomb GA, Whitsett TL, Wilson MF, Lovallo WR. Hypertension Risk Status and Effect of Caffeine on Blood Pressure. Hypertension. 2000;36(1):137-41.

10. Rodriguez-artalejo F, Lopez-garcia E, Mesas AE, Leon-mun LM. The effect of coffee on blood pressure and cardiovascular disease in hypertensive individuals: a systematic review and meta-analysis. Am J Clin Nutr. 2011;94(4):111326.

11. Zhang Z, Hu G, Caballero B, Appel L, Chen L. Habitual coffee consumption and risk of hypertension: a systematic review and metaanalysis of prospective observational studies. Am J Clin Nutr 2011;93(6):1212-19.

12. Robertson D, Robertson RM. Chronic Hypotension. Am J Hypertens. 1992;5(6 Pt2):200S-5S.

13. Hara A, Ohide H, Miyagawa K, Takeuchi T. Acute Effects of Caffeine on Blood Pressure and Heart Rate in Habitual and Non-Habitual Coffee Consumers: A Randomized, Double-Blind , Placebo-Controlled Study. Jpn J Pharm Heal Care Sci. 2014;40(7):383-388.

14. Nuttall FQ. Body Mass Index: Obesity, BMI, and Health: A Critical Review. Nutr Today. 2015;50(3):117-28.

15. Muntner P, Shimbo D, Carey RM, et al. Measurement of Blood Pressure in Humans A Scientific Statement From the American Heart Association. Hypertension. 2019;73:35-66.

16. Keefe JHO, Bhatti SK, Patil HR, DiNicolantonio JJ, Lucan SC, Lavie CJ. Effects of Habitual Coffee Consumption on Cardiometabolic Disease , Cardiovascular Health , and All-Cause Mortality. $J$ Am Coll Cardiol. 2013;62(12):1043-51.

17. Köksal E, Yardımcı H, Kocaadam B, Güneş BD, Karabudak E. Relationship between dietary caffeine intake and blood pressure in adults. Int $J$ Food Sci Nutr. 2017;68(2):1-8.

18. Myers MG. Effect of Caffeine on Blood Pressure Beyond the Laboratory. Hypertension. 2004;43(724-725):8-9.

19. Shepard JD, Absi M, Whitsett TL, Passey RB, Lovallo WR. Additive Pressor Effects of Caffeine and Stress in Male Medical Students at Risk for Hypertension. Am J Hypertens. 2000;13(5 II Suppl):475-81.

20. Hauton D, Ray CJ. Caffeine, gravity, and baroreceptor function: the integration of diet and cardiovascular control. Adv Physiol Educ. 2018;42(3):454-61.

21. Astorino TA, Martin BJ, Schachtsiek L. Caffeine Ingestion and Intense Resistance Training Minimize Postexercise Hypotension in 
Normotensive and Prehypertensive Men. Res Sport Med An Int J. 2015;21(1):52-65.

22. Rosita R, Budiastra IW, Sutrisno. Prediksi Kandungan Kafein Biji Kopi Arabika Gayo dengan Near Infrared Spectroscopy Prediksi Kandungan Kafein Biji Kopi Arabika Gayo dengan Near Infrared Spectroscopy. J Keteknikan Pertan. 2016;4(2):179-86.

23. Aditama HF, Budiastra IW, Riwayat SW. Pengembangan Model Jaringan Syaraf Tiruan untuk Penentuan Kandungan Kimia Biji Kopi Arabika Gayo dengan NIRS. J Agro-based Ind. 2019;36(1):22-9.
24. Farag NH, Whitsett TL, McKey BS, Wilson MF, Vincent AS, Everson-Rose SA, et al. Caffeine and Blood Pressure Response: $J$ women's Heal. 2010;19(6):1171-6.

25. Badkook MM, Shrourou RM. Arabic coffee with two doses of cardamom: effects on health biomarkers in healthy women. Int J Nutr Food Sci. 2013;2(6):280-6.

26. Corti R, Binggeli C, Sudano I, Spieker L, Hanseler E, Ruschitzka F, Chaplin WF, et al. Coffee Acutely Increases Sympathetic Nerve Activity and Blood Pressure Independently of Caffeine Content Role of Habitual Versus Nonhabitual Drinking. Circulation. 2002;106:2935-40. 